\title{
Chapter 6 \\ Indigenous Practices of Paddy Growers \\ in Bhutan: A Safety Net Against Climate \\ Change
}

\author{
Tshotsho
}

\section{Key Messages}

- This chapter provides a community resilience story of rice growers in Bhutan.

- Traditional knowledge usage can provide a way forward for building and securing livelihood in the fight against climate change.

- The traditional knowledge needs to be streamlined into the common policy debate.

\subsection{Introduction}

Climate change has profound impacts on agriculture (Cline, 2007). One of the most prominent forms of this impact is water scarcity (Balasubramanian \& Saravanakumar, 2022, Chap. 10 of this volume). The IPCC (2014) predicts as much as $50 \%$ loss in crop yield in rainfed agriculture that does not use any adaptation strategies. The drying-up of springs is a cause of concern in the hills and mountains of the Himalayas (Bharti et al., 2020; Rai \& Nepal, 2022, Chap. 23 of this volume), and the agricultural community faces a risk to its livelihood due to the short window of rainy season which is the only source of water for irrigation (Gurung \& Bhandari, 2009; Kattel \& Nepal, 2021, Chap. 11 of this volume). Agriculture in Bhutan is carried out on small

\footnotetext{
Disclaimer: The presentation of material and details in maps used in this book does not imply the expression of any opinion whatsoever on the part of the Publisher or Author concerning the legal status of any country, area or territory or of its authorities, or concerning the delimitation of its borders. The depiction and use of boundaries, geographic names and related data shown on maps and included in lists, tables, documents, and databases in this book are not warranted to be errorfree nor do they necessarily imply official endorsement or acceptance by the Publisher, Editor(s), or Author(s).
}

Tshotsho $(\bowtie)$

College of Natural Resources, Royal University of Bhutan, Lobesa, Bhutan

e-mail: tshotsho1993@gmail.com 
scale and mostly rain fed and dry land and wetland farming, and provides livelihood to over $57 \%$ of the population (ICTA \& World Bank, 2017). Since, the country is part of the Himalayas, the agriculture sector has been facing climate change impacts in the form of: reduction in agricultural water availability (increasing fallow land in rice cultivation due to lack of irrigation water); reduction in crop yield due to inadequate rainfall during the growing season; and erratic and excessive rainfall patterns leading to extreme events like flash floods, and reduced availability of arable land (ICTA \& World Bank, 2017).

A recent strategy by the Government of Bhutan is the adoption of Climate Smart Agriculture (CSA) (CIAT \& World Bank, 2017). CSA technologies are a set of agricultural technologies that include use of improved plants such as drought-tolerant, pest- and disease-resistant early-maturing seed varieties for cereals and vegetables; crop intensification such as maize intercropping with legumes; soil conservation and nutrient management such as manure; improved water and irrigation management such as drip irrigation; and alternate wetting and drying for paddy and upland rice cultivation. These adaptation technologies should be able to secure food security, increase food production and promote rural development (CIAT \& World Bank, 2017). However, funding for CSA technologies is limited and adversely impacts the safety nets without an alternative source of livelihood for farmers (CIAT \& World Bank, 2017).

In this situation, there is evidence of community adoption and mitigation through utilization of traditional agriculture knowledge (Galloway-McLean, 2017). Traditional knowledge can re-emerge, and traditional agriculture can become part of the resilience effort. The re-emergence and dependence on traditional agricultural knowledge will be driven by vulnerability originating from changes in climatic and environmental problems, further exacerbated by the lack of agricultural input and support (Shava et al., 2009). Among the many crop choices, farmers perceive rice to be more resistant to climate change (Bojang et al., 2020). Galloway-McLean (2017) present case studies from around the world that have cultivated paddy to build resilience to climate change, and the Mphunga community in Malawi, for example, have built resilience against climate change by switching from maize to rice. Farmers, for example, in Gambia, understand that water supply will be affected by climate change and rice production will reduce without adaptation measures and think that traditional rice varieties can withstand extreme weathers because they have survived for a long period (Bojang et al., 2020). The Nwadjahane community in Mozambique have sought to cultivate drought-resistant rice; and the Khagrachari community in Bangladesh relies on different varieties of rice to suit the recession of flood waters and duration of droughts, Dar et al. (2017) argue that farmers prefer traditional rice varieties over modern varieties because they give $30-42 \%$ more yield and are more flood-tolerant. Traditional local rice varieties have also been adopted as a climate change adaptation measure by the local community, because they have found it to be socially acceptable, economically beneficial, and environmentally sound in many parts of Bangladesh (Kabir \& Baten, 2019). 
This study looks at the adoption of traditional rice variety ${ }^{1}$ as a strategy in building resilience to climate change for households in the five gewogs ${ }^{2}$ of Punakha valley in west-central Bhutan. Specifically, the study proposes to: (a) identify the determinants which influence household's adoption of traditional local rice varieties with a focus on irrigation constraint; and (b) understand the extent of contribution of its adoption towards households' resilience. Estimates show that availability of water for irrigation has significant effect on farmer's decision to use traditional versus highyielding variety of rice. In the upper hill area, where water is scarce, farmers choose traditional rice variety of rice whereas in the valley area where irrigation water is available farmers choose high-yielding variety.

\subsection{Study Area and Sampling}

The study uses data from the Renewable Natural Resources Survey carried out in 2019. The survey provides recent information on demography, land holding and ownership, land use and irrigation, crops, livestock, farm mechanisation, credit, labour and forestry. Specifically, the study uses 1088 households from the five gewogs spread over the district of Punakha, which are highly vulnerable to climate change in terms of water stress. The selection of sample gewogs is based on telephone interview with gups, the heads of the gewogs. ${ }^{3}$ In instances where the gup had less information on the adoption and prevalence of rice variety, few Tshogpas ${ }^{4}$ were also approached over telephone to properly identity villages that had adopted four specific traditional rice varieties. ${ }^{5}$ They were asked whether they adopted the four specific local varieties; whether these adoption villages were in higher altitude; and whether they faced water scarcity. On the basis of the telephone interview, 5 out of 11 gewogs were retained for the analysis. These comprise 120 households from 8 chiwogs that adopted the traditional rice variety and 968 households from 25 chiwogs that did not adopt $^{6}$ it. The 968 households were retained because they are from the same gewogs, which makes the comparison more realistic. The households in the same gewogs

\footnotetext{
${ }^{1}$ These specific traditional variety includes Yangkum, Jama, Janaap and Jakaap in the local language. These varieties have two distinct characteristics. It grows in high altitude and requires short window for plantation and harvesting.

${ }^{2}$ A gewog is a sub-district. A district is a composition of several gewogs.

${ }^{3}$ Gups who heads a gewog in 11 gewogs in the district were approached over telephone. Gewogs are sub-district areas. Gups are referred to as the Chairman.

${ }^{4}$ Tshogpa heads a chiwog which is a sub-gewog.

5 "A farmers' variety is defined as a variety which has been traditionally cultivated by farmers in their fields, or is a wild relative of a variety about which farmers possess the common knowledge" (Ragavan \& O'shields, 2007).

${ }^{6}$ Non-adopter includes a village which may use either modern improved variety or other local varieties which are grown in lower altitude or valley wetlands.
} 
Table 6.1 Showing number of adopters and non-adopters of traditional rice varieties within different gewogs of Punakha

\begin{tabular}{l|l|l|l|l|l|c}
\hline \multirow{2}{*}{$\begin{array}{l}\text { Adoption of } \\
\text { traditional rice }\end{array}$} & \multicolumn{6}{l}{ Gewog } \\
\cline { 2 - 8 } & Barp & Guma & Lingmukha & Shelnga-Bjemi & Toedwang & Total \\
\hline No & 245 & 257 & 138 & 118 & 210 & 968 \\
\hline Yes & 8 & 10 & 12 & 46 & 44 & 120 \\
\hline Total & 253 & 267 & 150 & 164 & 254 & 1,088 \\
\hline
\end{tabular}

Note Figures represent count of households

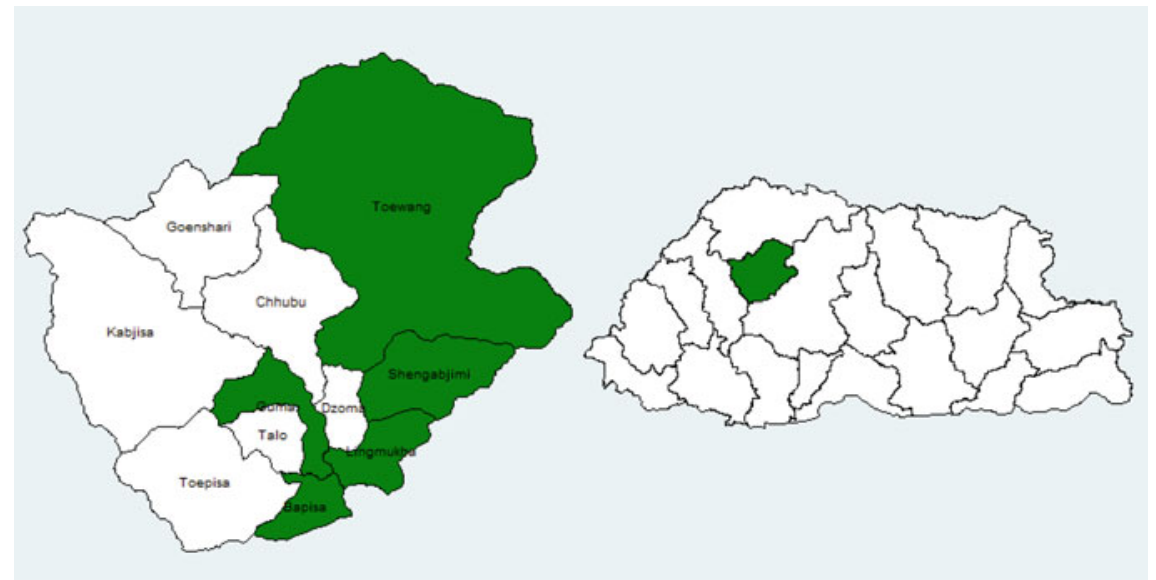

Fig. 6.1 Showing study sites where green shadings indicates selected gewogs for analysis

were found both in the lower valley and high altitude in the hilly areas, where they also faced water shortage resulting in irrigation problems (Table 6.1 and Fig. 6.1). ${ }^{7}$

The FGD ${ }^{8}$ interviews are with the adopters, and some discussion from the field with these adopters makes the case study interesting:

We grow Janaap which is originally brought from Shelngana, a village located in higher altitude in Punakha, and another variety, Jakaap brought from Lingmukha which is located in a higher altitude than our village. Due to customary laws regarding water usage, we get the

\footnotetext{
${ }^{7}$ Irrigation problems in these villages can exist in two forms. First, irrigation problems can exist because of a complete lack of irrigation water, which forces farmers to rely on monsoon rain. Second, irrigation water can be constrained because of customary law, which entitles households in upland to user rights first and households in lowland to later part of the plantation season. Due to decreasing volume in spring water and late arrival of monsoon, households in lowlands face only a few months (usually $4-5$ months) for planting and harvesting, as compared to upland who get longer duration (7-8 months). This constraint forces farmers to rely on traditional varieties that require short duration for ripening.

${ }^{8}$ FGDs were mostly carried out on the phone due to covid-19 issues. Discussions were also held with few farmers in person during a visit to some of the villages.
} 
water-use rights e late, in fourth and fifth month of the traditional calendar, ${ }^{9}$ while irrigation begins in the second month in the lower valley. We cultivate a mix of Jakaap and Janaap, because we have only $4-5$ months, till the ninth month which is the time for harvest. These rice varieties are suitable for short duration cropping system, and they ripen in the short duration. We even find that Jakaap is better than Janaap.

Village Tshogpa, Adopters

Yangkum and Jama are usually grown in the high altitude villages in Punakha. The plantation is carried out late and is completed by end of July. These villages start cultivation late when other chiwogs have already completed. Although the modern varieties have high yield and are early maturing, they are less tasty and have less demand in the market. Farmers prefer the local varieties because they mature late, are tasty and have high preference and demand in the market. They also rely on rain for irrigation which usually arrives late in the valley. They leave their land fallow if they miss this short window of rain water.

\section{Extension Officer}

We grow Jama and Yangkum which are the most preferred and suitable in our village. Jama is also cultivated in other village like Tamidamchu and Jojogoenpa. Jama is mostly grown because it is comparable in both taste and price to Ngabja which is found in the lower valley. These varieties are chosen because of the altitude and water shortage. They were passed down over generations. Yangkum takes longer duration to ripe and is planted during the fifth month and takes relatively more time as compared to Jama. Jama can be cultivated in the sixth month and ripens fast which is why they are adopted in our place which has irrigation constraints as we have to completely rely on rain. We cultivate these varieties as long as we have rain and leave our land fallow if there is shortage of rain. The production is half of what we usually cultivate because half of them do not ripe, when there is shortage of monsoon rain. We consume most of produce and sell some in the market.

2 Village women, Yuesikha, Adopters

\subsection{Methods and Variables}

The analysis of the study is based on the theory that links adoption of traditional rice varieties to changes in livelihood capitals, which enables households to build resilience to climate impacts using the sustainable livelihood approach (SLA). Asset or capacity building within the SLA model focuses on developing the resources and capacities that are required to secure livelihood on a sustainable basis. This framework provides a simple but well-developed way of thinking about complex issues (DFID, 2000). ${ }^{10}$ A description of the constraints faced by the farmers, along with other important variables such as economic activity, demographic conditions, land holding, irrigation and plantation methods, crop activities, income and labour hiring, will precede the analysis to provide an understanding of the institutional setup.

\footnotetext{
${ }^{9}$ Bhutanese traditional month is two months lag of the modern calendar. May (5th month) is only the 3rd month in the traditional calendar. The modern calendar is usually two months ahead of traditional calendar.

10 The DFID defines in the following sense: "a livelihood comprises the capabilities, assets (including both material and social resources) and activities required for a means of living. A livelihood is sustainable when it can cope with and recover from stresses and shocks and maintain or enhance its capabilities and assets both now and in the future".
} 
For the first objective, we try to provide a justification of whether farmers in the district are homogenous. For this, we try to compare the socioeconomic conditions and agricultural practises between the adopters and non-adopters of traditional rice varieties.

For the second objective, this paper examines how this adoption has contributed to the households' resilience and livelihood achievements (Rajan et al., 2015). Resilience is measured in terms of the household's ability to meet food requirements, percentage of income earned from agricultural production, area irrigated under paddy, quantity of paddy production, wetland area left fallow, and number of man days employed. These metrics of resilience are also the objectives pursued by the institutions and policies in Bhutan for promoting climate change adaptation and mitigation activities (CIAT \& World Bank, 2017). Although resilience should normally be studied over a long period of time requiring numerous observations, this study will use cross section data and attempt to understand household resilience at one time period, a robust and a comprehensive approach to understanding the impacts of the adoption, particularly in the absence of baseline information (Rajan et al., 2015).

\subsection{Results}

Table 6.2 shows the institutional settings under which the sampled farmers operate. These institutional settings show the constraints faced by the farmers from five gewogs. Among the constraints, irrigation is the dominant constraint (44\%) followed by labour shortage (24\%) and crop damage by wildlife (19\%). The sampled households represents other farmers in Bhutan who face shortage of land (15\%), crop damage by insects and disease (10\%), high labour charges $(9.7 \%)$ and lack of machinery (5\%). Most farmers have access to market and a little over $10 \%$ of the farmers have availed of credit.

Table 6.3 shows the descriptive statistics of the variables used in the analysis. More than half of the sampled farmers $(65.7 \%)$ engage in crop production as their main economic activity and $21.7 \%$ of the farmers are subsistence growers. During the time of interview, only $11 \%$ of the farmers had adopted four of the traditional rice varieties, with most of them using modern high-yielding rice introduced by the government through the extension centres, and other local varieties found in the lower valley. Most of the sample farmers have irrigated their field (92\%) using surface water irrigation. Out of mean land holding of 3.14 acres, two-thirds of the land was cultivated with paddy (2.03 acres) and one-third was left fallow (0.92 acres).

Apart from paddy cultivation as the main economic activity, farmers also engaged in the production of other cereals (94\%), legumes and oil (46.5\%), vegetables $(74.6 \%)$, root plants $(13 \%)$ and permanent crops $(53 \%)$. With $87 \%$ of them having employed labour, the mean average man days used was 55 days. These farmers also owned cattle (72\%). A small fraction of the farmers (7.7\%) also had protected land, and most of them (72\%) collected non-timber forest products. A majority $(93.8 \%)$ 
Table 6.2 Constraints facing farmers in food production and asset creation

\begin{tabular}{|c|c|c|c|}
\hline Variable & Obs & Mean & Standard deviation \\
\hline $\begin{array}{l}\text { Irrigation } \\
\text { constraint }\end{array}$ & 1088 & 0.44 & 0.49 \\
\hline Unproductive land & 485 & 0.01 & 0.12 \\
\hline Labour shortage & 615 & 0.24 & 0.42 \\
\hline High labour wages & 623 & 0.09 & 0.29 \\
\hline $\begin{array}{l}\text { Crop damage by } \\
\text { wild animals }\end{array}$ & 530 & 0.19 & 0.39 \\
\hline $\begin{array}{l}\text { Crop damage by } \\
\text { insect/diseases }\end{array}$ & 662 & 0.10 & 0.30 \\
\hline Drought & 498 & 0.00 & 0.06 \\
\hline Excessive rain & 595 & 0.00 & 0.04 \\
\hline $\begin{array}{l}\text { Hailstorm and } \\
\text { wind }\end{array}$ & 498 & 0.00 & 0.06 \\
\hline $\begin{array}{l}\text { Landslides and soil } \\
\text { erosion }\end{array}$ & 596 & 0.00 & 0.07 \\
\hline Shortage of land & 592 & 0.15 & 0.35 \\
\hline $\begin{array}{l}\text { Limited access to } \\
\text { market }\end{array}$ & 590 & 0.01 & 0.10 \\
\hline $\begin{array}{l}\text { Difficulty in } \\
\text { getting machinery }\end{array}$ & 583 & 0.05 & 0.22 \\
\hline Availed credit & 1088 & 0.10 & 0.30 \\
\hline
\end{tabular}

Note All the variables have minimum value of 0 and a maximum value of 1 since they are all dummy variables

of the farmers were able to meet all food requirements during the sampled year, and $42 \%$ of the sampled farmers earns $51-75 \%$ of their total income from crop production while $17,19.7$ and $21.7 \%$ of those farmers) earn between $0-25 \%, 26-50 \%$ and $76-100 \%$ of their income from crop production, respectively. Among the household heads, only $25 \%$ of them were male with an average age of 54 years and $78 \%$ of them were married.

\subsubsection{Are Farmers Homogenous?}

The main point of distinction between the adopters and non-adopters is that the former are mainly found in the high altitude areas lying on top of the valleys. The non-adopting farmers are found in the lower valley. Farmers in the lower valley areas also face water scarcity (Table 6.4). Farmers in the lower valleys are dependent on irrigation fed by surface running water. However, with climate change, paddy cultivation has become very difficult. The customary rules of sharing irrigation water have also made equitable sharing of water difficult. The government has responded 
Table 6.3 Description of variables and their statistics

\begin{tabular}{|c|c|c|c|c|}
\hline Variable & Description of variable & Obs & Mean & Std. dev \\
\hline Crop_activity & $\begin{array}{l}=1 \text { if crop production is the main economic } \\
\text { activity }\end{array}$ & 1088 & 0.65 & 0.47 \\
\hline Adopts_2TRV & $\begin{array}{l}=1 \text { if the household adopts traditional rice } \\
\text { variety }\end{array}$ & 1088 & 0.11 & 0.31 \\
\hline Food_security & $\begin{array}{l}=1 \text { if household is able to meet food } \\
\text { requirement }\end{array}$ & 1088 & 0.93 & 0.24 \\
\hline Irrigated & $=1$ if the household irrigated field & 1088 & 0.92 & 0.26 \\
\hline Irrigation_surface & $=1$ if surface irrigation practised & 1002 & 0.98 & 0.10 \\
\hline Irrigation_source & $=1$ if surface water is the source of irrigation & 1002 & 0.97 & 0.14 \\
\hline Male & $=1$ if household head is male & 1088 & 0.25 & 0.43 \\
\hline Age & Age of the household head & 1088 & 54.37 & 13.87 \\
\hline Married & $=1$ if head of household is married & 1088 & 0.78 & 0.41 \\
\hline Literate & $=1$ if head of household is literate & 1088 & 0.21 & 0.41 \\
\hline Hsize & Number of members in the household & 1088 & 3.47 & 1.72 \\
\hline Irripaddy & Area irrigated in acres & 966 & 2.03 & 1.43 \\
\hline Paddy_prod & Paddy produce in kilograms & 966 & 4792.52 & 3698.06 \\
\hline Land_holding & Area of land holding in acres & 1088 & 3.14 & 2.85 \\
\hline Fallow & Area of wetland left fallow in acres & 233 & 0.92 & 1.17 \\
\hline Cereals & $=1$ if cereal in grown & 1088 & 0.94 & 0.23 \\
\hline Legumes & $=1$ if legumes and oilseeds grown & 1088 & 0.46 & 0.49 \\
\hline Vegetables & $=1$ if vegetables grown & 1088 & 0.74 & 0.43 \\
\hline Roots & $=1$ if roots and tubers grown & 1088 & 0.13 & 0.34 \\
\hline $\begin{array}{l}\text { Permanent_Crops } \\
\text { Protected }\end{array}$ & $\begin{array}{l}=1 \text { if permanent crops grown } \\
=1 \text { if has protected land presence }\end{array}$ & $\begin{array}{l}1088 \\
1088\end{array}$ & $\begin{array}{l}0.53 \\
0.07\end{array}$ & $\begin{array}{l}0.49 \\
0.26\end{array}$ \\
\hline Livestock & $=1$ if bovine animals owned & 1088 & 0.72 & 0.44 \\
\hline LabourEmployed_ & $\begin{array}{l}=1 \text { if labour employed } \\
\text { Number of man days employed }\end{array}$ & $\begin{array}{r}1088 \\
950\end{array}$ & $\begin{array}{r}0.87 \\
55.88\end{array}$ & $\begin{array}{r}0.33 \\
37.40\end{array}$ \\
\hline NWFP & $=1$ non-timber forest products collected & 1088 & 0.72 & 0.44 \\
\hline \multirow[t]{4}{*}{ Income_RNR } & $0-25 \%$ & 1088 & 0.20 & \\
\hline & $26-50 \%$ & 1088 & 0.17 & \\
\hline & $51-75 \%$ & 1088 & 0.42 & 0.40 \\
\hline & $76-100 \%$ & 1088 & 0.19 & 0.37 \\
\hline Subsistence & $\begin{array}{l}=1 \text { if production is only for } \\
\text { self-consumption }\end{array}$ & 1088 & 0.21 & 0.49 \\
\hline
\end{tabular}

Source RNR Census (2019) 
Table 6.4 Mean comparison of social, economic and agricultural practises between adopters and non-adopters of traditional rice varieties

\begin{tabular}{l|l|l|l}
\hline Socioeconomic conditions & Non-adopters & Adaptors & $P$-value \\
\hline$=1$ if household faces irrigation constraint & 0.45 & 0.35 & $0.04^{* *}$ \\
\hline$=1$ if crop production is main economic activity & 0.63 & 0.87 & $0.00^{* * *}$ \\
\hline$=1$ if head of household is married & 0.78 & 0.76 & 0.64 \\
\hline$=1$ if head of household is female & 0.25 & 0.28 & 0.42 \\
\hline Age of household head & 54.35 & 54.55 & 0.88 \\
\hline Household size & 3.46 & 3.50 & 0.80 \\
\hline$=1$ if household collects NWFP & 0.71 & 0.82 & $0.01^{* *}$ \\
\hline Land holding in acres & 3.12 & 3.30 & 0.52 \\
\hline$=1$ if household grows Legumes and oil & 0.46 & 0.43 & 0.46 \\
\hline$=1$ if household grows vegetables & 0.75 & 0.69 & 0.14 \\
\hline$=1$ if household grows roots & 0.14 & 0.09 & 0.14 \\
\hline$=1$ if household grows permanent crops & 0.52 & 0.60 & $0.07 *$ \\
\hline$=1$ if household has land under protection & 0.07 & 0.07 & 0.92 \\
\hline
\end{tabular}

All estimates were tested for a significance level of ***(10\%), **(5\%), *(1\%)

to these problems by encouraging modern high-yielding varieties. Farmers in the lower valleys prefer to use varieties that are also sold easily in the market and are preferred by customers visiting local market.

Paddy rice cultivation comprises the majority of the occupational crop of most farmers in the Punakha valley. Farmers in the hilly areas have been exclusively subsistence crop growers and have refrained from engaging in cash crops. This could be due to distance from the market. In contrast, farmers in the lower valleys, because of proximity to market, have found growing oilseeds, legumes, vegetables and root crops such as potatoes more profitable. Field data also supports this argument (Table 6.4). Farmers in both the groups are also members of community forest and are surrounded by protected areas. These community forests are mostly in the hilly regions and have provided farmers there with non-timber forest products like mushrooms, wild fruits, firewood and fodder for their domesticated animals. Data shows that the adopting group collects relatively more of these resources from the protected forest (Fig. 6.2 and Table 6.4).

Field visits to the valley have shown that farmers in the study site can be considered as homogenous. There is plenty of evidence against social heterogeneity among farmers in the district. Data shows that there is no significant difference between farmers who adopt traditional rice varieties when compared to non-adopters. In terms of asset ownership, both the groups of farmers have similar land holding measured in acres (Fig. 6.2 and Table 6.4). These are all smallholder farmers with none holding land above 5 hectares. The household size, age, gender and marital status also play 

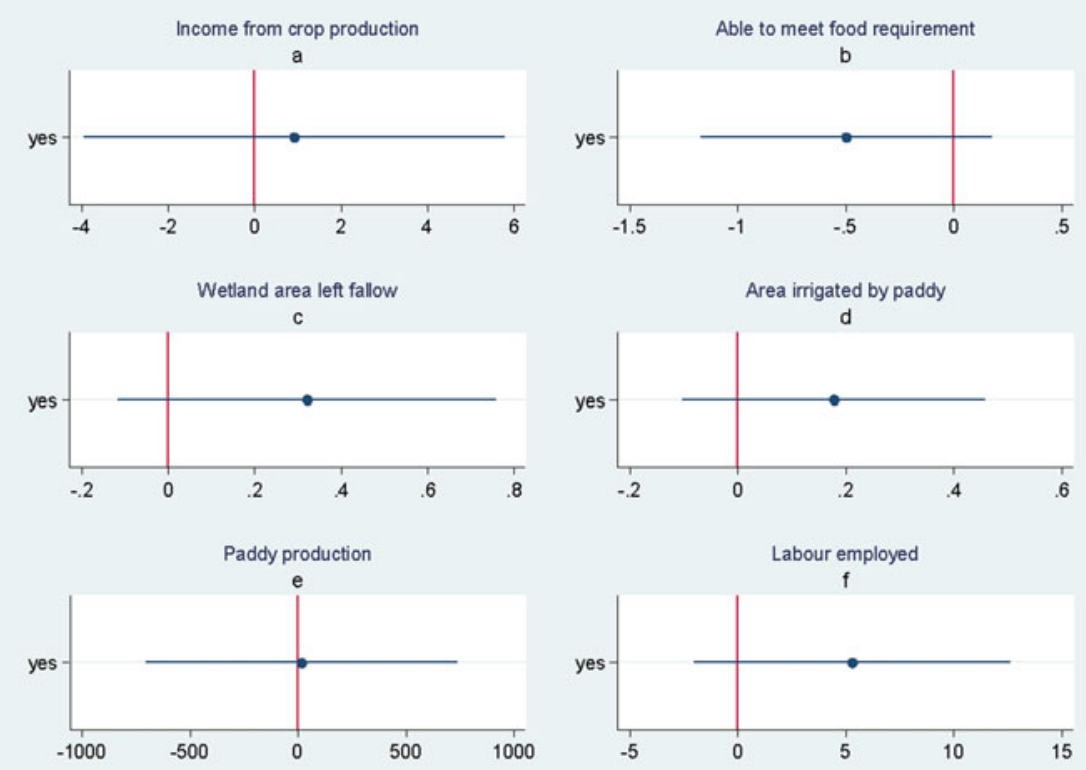

Fig. 6.2 Coefficient estimates of livelihood measures from adoption of traditional rice variety. Note a estimated using interval regression (Long \& Freese, 2006), $(P=0.71)$, b estimated using logit regression (Wooldridge, 2016) $(P$ value $=0.15), \mathbf{c}(P$ value $=0.15), \mathbf{d}(P$ value $=0.21), \mathbf{e}(P$ value $=0.96)$ and $\mathbf{f}(P$ value $=0.15)$ estimated using linear regression (Wooldridge, 2016)

an important role in decision-making that can have an impact on livelihood achievements. Data shows that there is no significant difference between growers and nongrowers of traditional rice varieties for these socioeconomic conditions too (Fig. 6.2 and Table 6.4).

\subsubsection{Are Livelihood Achievements Comparatively Similar?}

It has been argued that farmers in both the groups are homogenous except that those in the higher hilly areas have resorted to traditional varieties that were passed on by ancestors while modern high-yielding and high-demand rice varieties are preferred by farmers in the lower valleys. If farmers adopting traditional varieties are a rational decision maker, then these decisions should also offer farmers comparable livelihood achievements. These livelihood achievements can be compared and tested for how farmers are able to meet food requirements, income earned and rice production since it is the primary employment of these farmers.

A cursory glance over their ability to meet food requirement shows that nonadopters are able to meet more food requirements compared to the adopters (Fig. 6.2). 
This could be true because farmers in the lower valleys not only grow paddy but also engage in production of oilseeds, legumes, vegetables and root crops such as potatoes. Rice and potato constitute a major staple diet in Bhutan along with legumes such as beans and peas. But statistically the differences are not so huge or significant (Fig. 6.2). This implies that since rice is the primary production crop and the staple diet, and since farmers perceive food security in terms of their ability to meet three meals of rice, traditional rice growers are no less than the group which grows modern varieties.

This can be further substantiated by understanding income earned by farmers. Farmers in the lower valleys are closer to market and can sell their rice and vegetables in the market that opens on a weekly basis. But, mean comparison data shows that there is hardly any income difference between these groups (Fig. 6.2). This could be due to two reasons. First, the traditional rice, if brought to the market, fetches higher price due to superior taste over the rice grown in the lower valleys. Second, farmers in the hills sell their labour to farmers in the lower valleys because the formers' paddy cultivation starts later in late August and September, two months later than the time of the paddy cultivation in the valleys.

Farmers in the hills also cultivate more area of the field, which explains higher number of labour employed (Fig. 6.2) and yet they produced same quantity of paddy like the lower valley farmers. One explanation could be that the rice varieties in the lower valley that are provided by the government are high yielding. So, there is a quantity and quality trade-off here. However, more land were left fallow in the lower valley area too. The land ownership system offers an explanation to this. In the lower valleys, most of the farmers are sharecroppers although they also own some land. When farmers cultivate on land that belongs to others, they face more incentive to cultivate as much as they can, contrary to farmers in the hilly region where lands are privately owned and farmers being subsistence farmers, grow only what will be sufficient for the year. The phenomenon of out-migration could also offer another explanation. However, the differences are not huge or significant enough (Fig. 6.2); otherwise we would be tempted to conclude that traditional rice varieties are inferior to the modern varieties.

Finally, higher labour employed by adopters could be related to higher area of land irrigated compared to the non-adopting group (Fig. 6.2). This also has no significant statistical difference (Fig. 6.2). All these evidence shows that the two groups are comparable in livelihood measures.

\subsection{Discussion and Conclusion}

Much of research in rice adoption in Bhutan has focused on adoption alone, except one which has gone beyond and estimated the impact of adoption on livelihood measures such as poverty, to provide better policy recommendations (Bannor et al., 2020). This is important because simply adopting a variety does not guarantee resilience. This study followed a similar approach and compared livelihood impacts 
between adopters and non-adopters of traditional rice varieties. This paper tested the question whether farmers adopting traditional rice varieties in the hilly regions have the same adapting capacity and offer resilience from climate change, as compared to modern rice improved varieties which are often the most propagated. Estimated results show that they both have the same capacity. The result from this paper is in line with studies that have shown that traditional food crops have enabled households to meet food requirements and maintain food security (Shava et al., 2009).

Traditional agriculture has also helped to increase production and reduce food insecurity in communities in China, Kenya and Bolivia (Swidersk et al., 2011). In contrast, replacing traditional variety by modern high-yielding variety is found to have resulted in more rice production and has improved food security in Bangladesh (Shew et al., 2019). This is also in contrast to a study which shows yield production is more in modern variety as compared to traditional variety in the western region of Punakha and Wangdue Phodrang district, where $56 \%$ of the farmers adopted modern rice variety through promotion by the government (Chhogyel \& Bajgai, 2015).

Farming communities who use community seed variety have also empowered poor farmers and women and have increased their income by $30 \%$ (Swidersk et al., 2011). In the Indian State of Uttarakhand, a study shows that adoption of traditional rice like basmati earned more net income compared to non-adopters (Jena \& Grote, 2012). Although some studies report higher income earnings, we found insignificant difference between different rice adopters. In contrast to these results, Bannor et al. (2020) show that compared to traditional variety, adoption of modern improved variety leads to reduction in poverty gap and incidence. They also show that modern variety households have higher monthly household expenditure.

Although we find studies comparing traditional and modern improved rice varieties in terms of adoption and impact on food production, income and food security, there is a lack of studies showing the effect of adoption on the area of wetland left fallow and number of man days employed. This study uses a multitude of resilience measurements to find a robust comparison of adopters of traditional rice variety in comparison with modern rice variety along with other local varieties.

Although traditional agriculture along with their crops are facing threat from modern commercial food systems, this paper argues that traditional knowledge is capable of providing resilience towards climate change (Shava et al., 2009). There is a strong evidence how traditional knowledge makes a community reluctant to adopt modern varieties. Swidersk et al., (2011) argue that "Indigenous peoples and local communities often live in harsh natural environments, and have had to cope with extreme weather and adapt to environmental change for centuries in order to survive. They have done this using long standing traditions and practices relating to adaptive ecosystem management". They further argue that it is important to develop and promote context-dependent education and awareness on the coping opportunities provided by traditional crops (Shava et al., 2009; Swidersk et al., 2011).

This paper presented a case of paddy growers in Punakha valley, who have resorted and continue to adopt four rice varieties which have proved to provide a way forward in sustaining their livelihoods in the face of climate change. Specifically, this paper provides an account of the institutional context in which these farmers operate, and 
the farming technology that they use and compares it with communities that face similar situations but have access to other options.

Acknowledgements I would like to thank the villagers of Yuesikha who have first shared their resilience story and how irrigation has seriously constrained their way of life. I also want to thank them for hosting my students in 2018 and colleagues in 2017 who were together with me eager to learn about their livelihood and story. Special appreciation also goes to the Gups of all the gewogs and Tshogpas of few chiwogs, and extension officers in Punakha dzongkhag, who were willing to answer the questions I have asked them through telephone. Special appreciation goes to the editors for giving me this opportunity to write and share this incredible story from Bhutan.

\section{References}

Balasubramanian, R., \& Saravanakumar, V. (2022). Climate sensitivity of groundwater systems in South India: Does it matter for agricultural income? In A. K. E. Haque, P. Mukhopadhyay, M. Nepal, \& M. R. Shammin (Eds.), Climate change and community resilience: Insights from South Asia (pp. 143-156). Springer.

Bannor, R. K., Kumar, G. A. K., Oppong-Kyeremeh, H., \& Wongnaa, C. A. (2020). Adoption and impact of modern rice varieties on poverty in Eastern India. Rice Science, 27(1), 56-66.

Bharti, N., Khandekar, N., Sengupta, P., Bhadwal, S., \& Kochhar, I. (2020). Dynamics of urban water supply management of two Himalayan towns in India. Water Policy, 22(S1), 65-89.

Bojang, F., Traore, S., Togola, A., \& Diallo, Y. (2020). Farmers perceptions about climate change, management practice and their on-farm adoption strategies at rice fields in Sapu and Kuntaur of the Gambia, West Africa. American Journal of Climate Change, 9(01), 1.

Chhogyel, N., \& Bajgai, Y. (2015). Modern rice varieties adoption to raise productivity: A case study of two districts in Bhutan. SAARC Journal of Agriculture, 13(2), 34-49.

CIAT; World Bank. (2017). Climate-smart agriculture in Bhutan. CSA country profiles for Asia series. International Center for Tropical Agriculture (CIAT); The World Bank. Washington, D.C. $26 \mathrm{p}$.

Cline, W. R. (2007). Global warming and agriculture: Impact estimates by country. Peterson Institute.

Dar, M. H., Chakravorty, R., Waza, S. A., Sharma, M., Zaidi, N. W., Singh, A. N., \& Ismail, A. M. (2017). Transforming rice cultivation in flood prone coastal Odisha to ensure food and economic security. Food Security, 9(4), 711-722.

DFID, G. S. (2000). Sustainable livelihoods guidance sheets, Section 2. Framework.

Galloway-McLean, K. (2017). Advance guard: Climate change impacts, adaptation, mitigation and indigenous peoples: A compendium of case studies.

Gurung, G. B., \& Bhandari, D. (2009). Integrated approach to climate change adaptation. Journal of Forest and Livelihood, 8(1), 91-99.

IPCC. (2014). Summary for policymakers. In O. Edenhofer, R. Pichs-Madruga, Y. Sokona, E. Farahani, S. Kadner, K. Seyboth, ..., \& J. C. Minx (Eds.), Climate Change 2014: Mitigation of Climate Change. Contribution of Working Group III to the Fifth Assessment Report of the Intergovernmental Panel on Climate Change. Cambridge University Press.

Jena, P. R., \& Grote, U. (2012). Impact evaluation of traditional Basmati rice cultivation in Uttarakhand State of Northern India: What implications does it hold for geographical indications? World Development, 40(9), 1895-1907. 
Kabir, M. H., \& Baten, M. A. (2019). Climate change adaptation practices to water sector in South-Western coastal area of Bangladesh.

Kattel, R. R., \& Nepal, M. (2021). Rainwater harvesting and rural livelihoods in Nepal. In A. K. E. Haque, P. Mukhopadhyay, M. Nepal, \& M. R. Shammin (Eds.), Climate change and community resilience: Insights from South Asia (pp. 159-173). Springer.

Long, J. S., \& Freese, J. (2006). Regression models for categorical dependent variables using Stata. Stata press.

Ragavan, S., \& O'shields, J. M. (2007). Has India addressed its farmers' woes-a story of plant protection issues. Georgetown Environmental Law Review, 20, 97.

Rai, R. K., \& Nepal, M. (2022). A tale of three Himalayan towns: Would payment for ecosystem services make drinking water supply sustainable? In A. K. E. Haque, P. Mukhopadhyay, M. Nepal, \& M. R. Shammin (Eds.), Climate change and community resilience: Insights from South Asia (pp. 357-367). Springer.

Ranjan, R., Pradhan, D., Reddy, V. R., \& Syme, G. J. (2015). Evaluating the determinants of perceived drought resilience: An empirical analysis of farmers' survival capabilities in droughtprone regions of South India. In Integrated assessment of scale impacts of watershed intervention (pp. 253-285). Elsevier.

Rath, N. C., Das, L., Mishra, S. K., \& Lenka, S. (2007). Adoption of upland rice technologies and its correlates. ORYZA-an International Journal on Rice, 44(4), 347-350.

Renewable Natural Resources Statistics Division Directorate Services. (2019). RNR Census of Bhutan, Thimphu. Ministry of Agriculture and Forests.

Shava, S., O'Donoghue, R., Krasny, M. E., \& Zazu, C. (2009). Traditional food crops as a source of community resilience in Zimbabwe. International Journal of African Renaissance Studies, 4(1), $31-48$

Shew, A. M., Durand-Morat, A., Putman, B., Nalley, L. L., \& Ghosh, A. (2019). Rice intensification in Bangladesh improves economic and environmental welfare. Environmental Science \& Policy, 95, 46-57.

Swiderska, K., Reid, H., Song, Y., Li, J., Mutta, D., Ongogu, P., \& Barriga, S. (2011). The role of traditional knowledge and crop varieties in adaptation to climate change and food security in SW China, Bolivian Andes and coastal Kenya. IIED.

Wooldridge, J. M. (2016). Introductory econometrics: A modern approach. Nelson Education.

Open Access This chapter is licensed under the terms of the Creative Commons AttributionNonCommercial-NoDerivatives 4.0 International License (http://creativecommons.org/licenses/bync-nd/4.0/), which permits any noncommercial use, sharing, distribution and reproduction in any medium or format, as long as you give appropriate credit to the original author(s) and the source, provide a link to the Creative Commons licence and indicate if you modified the licensed material. You do not have permission under this licence to share adapted material derived from this chapter or parts of it.

The images or other third party material in this chapter are included in the chapter's Creative Commons licence, unless indicated otherwise in a credit line to the material. If material is not included in the chapter's Creative Commons licence and your intended use is not permitted by statutory regulation or exceeds the permitted use, you will need to obtain permission directly from the copyright holder.

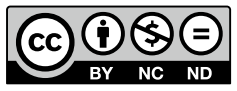

